\title{
Effect of long term Treatment of Chlorpromazine and Diazepam on the activity of acetyl cholinesterase in the chicks' blood
}

\author{
Luaay K. Yacoub \\ Dept. of Basic Science/College of Dentistry/University of Mosul
}

Received

$5 / 2 / 2006$
Accepted

4/9/2006

\section{الملخص - الم}

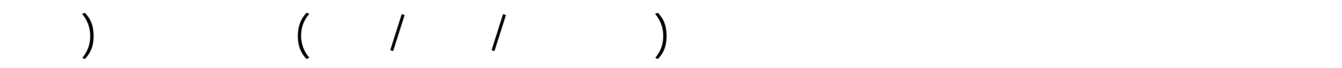



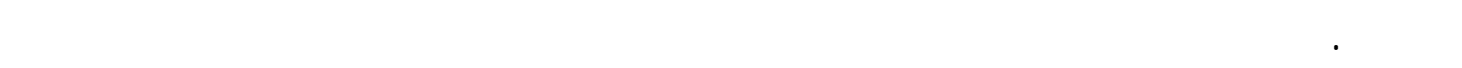

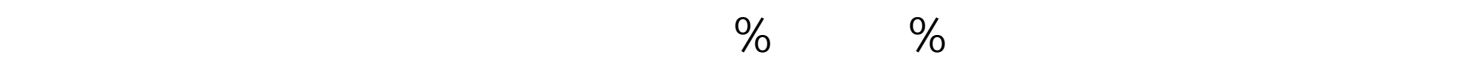



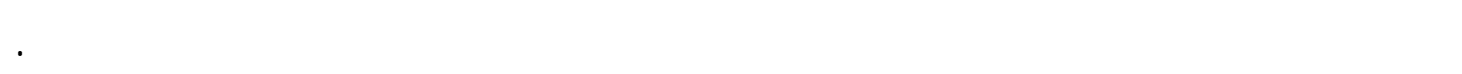

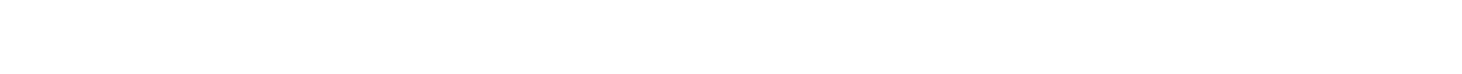
الإنتيل كولين لستراز فى دم افراخ الدجاج.

\begin{abstract}
Administration of chlorpromazine at ( $50 \mathrm{mg} / \mathrm{kg} /$ day ) orally for a period of 21 days resulted in a significant increase in chick blood plasma and RBC acetyl cholinesterase activity by $48 \%$ and $62 \%$ respectively , where as only a slight and non significant increase by $9 \%$ and $13 \%$ respectively was observed when diazepam was given at ( $30 \mathrm{mg}$ $/ \mathrm{kg} /$ day ) orally in comparison with control group .The result suggest that chronic treatment with chlorpromazine may stimulate blood acetyl cholinesterase activity in chicks .

\section{Introduction}

Acetyl cholinesterase (Ache ) is a cell microsomal membrane bound enzyme found in different tissues and play a responsible role for regulation of most physiological event, involving the turnover of acetylcholine( $1,2,3)$. A number of psychotropic drugs that change blood and/or 'true' Ache activity is known to affect various neurophysiologic and metabolic functions at cellular and molecular levels $(1,4)$.
\end{abstract}


Administration of chlorpromazine to chicks and/or rabbits increases the concentration of Ache in the brain and cerebrospinal fluid $(5,6)$. And the increase in levels of enzyme activity by chlorpromazine in certain brain regions depends on the duration of drug administration $(6,7)$. Long - term treatment with chlorpromazine resulted in significant increase in chick and rat 'true' Ache activity $(3,6)$. Diazepam in rats and /or chicks change (non significantly) the level of Ache in The brain $(3,6,17)$. The present study was undertaken in chicks to examine Ache activity following chronic administration of chlorpromazine and diazepam.

\section{Materials and Methods}

Twenty- one chicks $2-2.5$ months old and weighing $300-350$ g were used .They were housed under standard condition of temperature ( $27 \mathrm{C}$ ) and humidity, and had free access to food ( Commercial chick ration , Nebrese Co ., Mosul , Iraq . ) and water . The birds were divided into three groups of 7 chicks each. Control chicks were treated with physiological saline solution at $1 \mathrm{ml} / \mathrm{kg} /$ day. The remaining two groups were treated with chlorpromazine (May and Baker Co., England ) at 50 $\mathrm{mg} / \mathrm{kg} /$ day orally and diazepam ( Arab Pharmaceutical Manufacturing Co., Jordan ) at $30 \mathrm{mg} / \mathrm{kg} /$ day orally . The volume of administration of both drugs was $1 \mathrm{ml} / \mathrm{kg}$ body weight. Treatment was continued daily for 21 day. At the end of experimental period, chicks were sacrificed after ether anesthesia, and blood was rapidly collected. Blood samples were deranged by using treated heparinized syringe (Braun, Germany) and separated plasma from RBC by centrifugation in (3000 rpm) for $10 \mathrm{~min}$. Samples of blood stored in -20 C until the time of estimation of the enzyme activity ( $7-10$ days ) . $0.2 \mathrm{ml}$ from plasma and RBC samples was used for Ache activity measurement using acetylthiocholine iodide (7.5 \%) (Fluka, Switzer land) (8). All assays were done in duplicate. The statistical significance of the differences between mean values were analyzed by student's paired't ' test (9). The level of significance was at $\mathrm{p}$ $<0.01$.

\section{Results and Discussion}

Chronic chlorpromazine administration to chicks at $50 \mathrm{mg} / \mathrm{kg} / \mathrm{day}$ significantly increases plasma and RBC Ache activity by $48 \%$ and $62 \%$ respectively in comparison with the control group as shown in table. While chronic diazepam treatment at $30 \mathrm{mg} / \mathrm{kg} /$ day caused only a slight but non significant increase in both plasma and RBC enzyme activity which was about $9 \%$ and $13 \%$ respectively of the control group . Estimation of acetyl cholinesterase activity is of importance in studies concerning enzyme synthesis mechanisms (10-12). In the present study, we found that long-term administration of chlorpromazine increased blood Ache activity. This effect seemed to be due to accelerated turnover of Ach $(3,12,13)$. Possibly through change in cell membrane associated 
properties ( 3,5,14,15), any drug which alter the composition of cell microsomal membrane would also affect the enzyme -bound activity $(1,3,5,14,15)$. On the other hand, increased Ach turnover might cause adaptive change in the enzyme activity for Ach synthesis and degradation ( 3,14 ).Similarly , 21 day of haloperidol treatment is associated with cell microsomal membrane enzyme-bound activity ( 3,7,14 ). Stimulation of the enzymatic activity observed in the present study may be partly due to cell membrane effect of this drug $(2-4,16)$. The non significant change of enzyme activity by diazepam is in accordance with other reports $(3,4,17)$.

\section{References}

1- Adhikary J G, Nandy P, Chandra S, Sikder R and Sen P C, Biochem. Int., 25, 5,951-961 (1991).

2- Cohen B M and Zubenko G S, Psychopharmacol. 86, 365368(1985).

3- Spinedi A , Pacini L , Limatola C, Luly P, Farias R N, J. Biochem., 278,2,461-465(1991).

4- Oner B S and Eryurek F G, Neuro. Psychopharmacol and Biol.Psychiat. 18, 555-562(1994).

5- Greenfield S A, Ghabb I W and Smith A D, Neuropharmacol. 18, 127-132(1989).

6- Yakoub L K, J.Edu. Sci., 36, 81-85 (1999).

7- Mahadik S P, Laen H, Korenovsky A and Karpiak S E, Biol.Psychiatry., 24, 199-217(1988).

8- Mohammad F K and St Omer V E V, Minire view. Vet. Hum. Toxicol. 24, 119-121 (1982).

9- Burning J L and Kintz B L, Glenview, IL. Foremen and Co., 18 (1975).

10- Deutsch S I , Mohs R C , Leny M I , Rothpeale A B , Stockon D and Horvath T, Biol-Psychiatry., 18, 1363-1373 (1993).

11- Banerjee J, Ghosh P, Mitra S, Ghosh N and Bhattacharya S, J. oxicol. Environm. Health. 33, 283-290(1991).

12- Stadler H, Lloyd K G, Gadea M and Bartholini G, Brain. Res., 55,476-480 (1993).

13- Traboucchi M, D. Cheney D, G. Racagni G and Costa E, Nature. 249, 664-666 (1974).

14- Ahyayauch H, Goni F M, Bennouna M, J. Liposome. Res., 13, 2,147-155(2003).

15- Muller T C, Rocha J B, Mersch U M, Neis R T, Schetinger M R, Biochem. Biophys. Acta. 21, 1587, 92-98 (2002).

16- Henry J A and Cassidy S L, Lancet. 1, 1414-1417 (1986).

17- Shin T M, Brain. Res. Bull., 26, 4, 565-573 (1991). 
Table: blood acetyl cholinesterase activity in chicks treated orally with chlorpromazine and diazepam at 50 and $30 \mathrm{mg} / \mathrm{kg} /$ day, respectively for 21 days.

\begin{tabular}{|c|c|c|c|c|}
\hline \multirow{2}{*}{ Treatment } & \multicolumn{4}{|c|}{$\Delta$ pH/ 30 min Ache activity } \\
\cline { 2 - 5 } & Plasma & $\%$ Increase & Red Blood Cell & Increase \\
\hline Saline ( control ) & $0.33 \pm 0.01$ & & $0.29 \pm 0.03$ & $62 \% *$ \\
\hline Chlorpromazine & $0.49 \pm 0.02 *$ & $48 \% *$ & $0.47 \pm 0.03 *$ & $13 \%$ \\
\hline \hline Diazepam & $0.36 \pm 0.01$ & $\mathbf{9 \%}$ & $\mathbf{0 . 3 3} \pm 0.01$ & 6 \\
\hline
\end{tabular}

* $\mathbf{P}<\mathbf{0 . 0 1}$ Versus Saline control group. The values are mean $\pm \mathrm{S} E$ of 7 chicks / group. 